process. Given the frequent cases of leveling this ethical norm and its mass systematic violation, the concept of academic integrity has been transformed into a legal category. In particular, the legislative consolidation of this term and the formation of academic integrity as a legal category took place with the adoption of the Law of Ukraine «On Education». Since then, academic integrity has become one of the most important principles of public policy in the field of education.

The opinions of scientists on the reasons for violating the rules of academic integrity are summarized. Among them: poor mastery of research methods; relying on inappropriate recommendations for links; misunderstanding of the logic and rules of indicating sources; weak essay writing skills; imperfection of legal support in this area; insufficient technical capacity of various educational institutions to detect plagiarism; imbalance of training programs and loads, etc.

The main ways to overcome violations of the rules of academic integrity are identified. There are: timely assignment; tracking the phased implementation of the applicant of the research project; introduction of the academic discipline «Academic Writing» to the curricula of universities, etc.

Keywords: academic integrity, ethical and legal nature of academic integrity, rules of academic integrity, reasons for violation of rules of academic integrity.

DOI: 10.33766/2524-0323.92.86-93

УДК 347.73:347.457(477)

В. С. Бугайчук, аспірант кафедри конституційного, адміністративного та фінансового права Академії праці, соціальних відносин і туризму (м. Київ, Україна) e-mail: vnutr@ukr.net iDhttps:/ / orcid.org/0000-0002-9739-4370

\title{
ПРАВОВА ХАРАКТЕРИСТИКА РЕГУЛЮВАННЯ КРЕДИТНО-РОЗРАХУНКОВИХ ВІДНОСИН КРІЗЬ ПРИЗМУ ДОСВІДУ КРАЇН ЄВРОПЕЙСЬКОГО СОЮЗУ
}

У статті досліджено сутність поняття кредитно-розрахункових відносин, охарактеризовано різні підходи та класифікаційні особливості правового регулювання таких відносин з урахуванням досвіду країн Свропейського Союзу. Установлено, що передумовою виникнення розрахункових відносин є явище правової дійсності. Проведено розмежування понять «розрахунки», «розрахункові правовідносини» та «кредитно-розрахункові відносини». Здійснено класифікацію розрахункових відносин. Проаналізовано кредитно-розрахункові відносини в деяких країнах Європейського Союзу та запропоновано здійснити перетворення, які сприятимуть вдосконаленню правового регулювання досліджуваних відносин.

Ключові слова: розрахунок, платіж, правовідносини, кредитно-розрахункові відносини, юридичний зміст розрахункових відносин, СС.

Постановка проблеми. Проблеми, пов'язані з розрахунками та розрахунковими відносинами, залишаються актуальними вже декілька століть поспіль, позаяк кредитно-розрахункові відносини як наукова категорія - поняття багатогранне, що 
постійно потребує дослідження й пошуку нових шляхів удосконалення. Особливість указаних відносин обумовлюється тим, що вони невпинно розвиваються. Притому важливим є з' ясування правового регулювання кредитно-розрахункових відносин крізь призму досвіду країн Свропейського Союзу (далі - СС).

Аналіз останніх досліджень і публікацій. Питання розрахунків і кредитнорозрахункових відносин є предметом багатьох наукових досліджень. Такі вчені, як І. А. Безклубий, Ю. В. Ващенко, Л. К. Воронова, С. С. Компанієць, О. П. Орлюк, Л. В. Руденко, П. А. Тамаров, Т. Г. Тімакова, Я. О. Хірс у своїх працях приділяли увагу дослідженню особливостей правового регулювання кредитно-розрахункових відносин. У деяких фундаментальних наукових працях розглядалися лише окремі питання розрахункових відносин. Зокрема, розрахунки як наукова категорія були предметом дослідження О. П. Подцеркового в дисертації «Організаційно-правові основи розрахункових відносин у господарському комплексі Україні» (1999 р.) [1, с. 12], а Я. О. Хірс свою дисертацію «Цивільно-правове регулювання розрахункових відносин за законодавством України» (2011р.) присвятив лише вивченню проблем правового регулювання розрахункових відносин за цивільним законодавством України [2, с. 3]. В. I. Теремецький у співавторстві з іншими науковцями грунтовно дослідив питання контролю Фонду гарантування вкладів фізичних осіб за діяльністю банків як різновиду управлінської діяльності, що реалізується в межах регулятивної діяльності Фонду [3, с. 79].

Однак сьогодні поза межами комплексного дослідження залишається з'ясування питань різногалузевої природи розрахункових відносин та визначення місця розрахунків і платежів у цих відносинах, враховуючи євроінтеграційний курс України. Водночас не приділено належної уваги дослідженню досвіду країн СС щодо регулювання кредитно-розрахункових відносин.

Формулювання цілей. Метою статті є дослідження сутності поняття «кредитно-розрахункових відносин», характеристика різних підходів та класифікаційних особливостей правового регулювання таких відносин з урахуванням досвіду країн ЄC.

Виклад основного матеріалу. Предметом посиленої уваги науковців та практиків завжди були і залишаються розрахунки як фундаментальна основа та рушійна сила економіки держави. Загальновідомо, що якісне та ефективне правове регулювання розрахунків значною мірою залежить від теоретичної розробки питань їх здійснення.

У науковій літературі можна віднайти різні погляди вчених щодо трактування понять «розрахунки», «розрахункові правовідносини», «кредитно-розрахункові відносини». Їх можна розглядати як у широкому, так і вузькому значеннях. Відтак, Ю. В. Ващенко пропонує під розрахунками в широкому їх тлумаченні розуміти будь-який спосіб припинення зобов' язань (як грошових, так і негрошових) між сторонами, зокрема виконання зобов' язання в натурі та зарахування однорідних зустрічних (послідовних) вимог (широке значення терміна «розрахунки») [4, с. 180]. Якщо розглядати досліджуване поняття у вузькому розумінні, то під поняттям «розрахунки» розуміють саме грошові зобов'язання (обов'язки) сторін, платежі. У такому значенні поняття «розрахунки» нерідко обмежують сферою 
безготівкових розрахунків, що здійснюються суб'єктами господарювання через фінансово-кредитні установи» [2, с. 6]. Таку думку поділяють Л. О. Новосьолова [5, с. 21] і Т. Г. Тімакова [6, с. 109]. Вважаємо, що розрахунки не слід зводити до якоїс певної форми, а відтак ототожнення розрахунків як процесу розрахункових відносин із формами розрахунків (грошова, готівкова, безготівкова форми) слід вважати помилковим. Що стосується розрахункових відносин, то вони за своєю природою є різноманітними та складними водночас. Для ефективного регулювання порядку здійснення розрахунків необхідно чітко розуміти сутність таких відносин, їх зміст та особливості. 3’ ясування сутності розрахункових відносин можливе через здійснення одного з найрозповсюдженіших прийомів юридичної техніки, що використовують учені-юристи в цілях встановлення істини при дослідженні правових явиш, рішень, тих чи інших наукових завдань - класифікації, яка всебічно розкриє уявлення про те, які є види розрахунків.

3 огляду на вказане, класифікацію розрахункових відносин варто здійснювати за такими критеріями:

1) форма розрахунку: готівкова, безготівкова;

2) спосіб платежу - види розрахунків (акредитив, інкасо тощо);

3) спеціальний суб'єкт розрахункових відносин: юридична (банк) або фізична особа;

4) сфера поширення: внутрішньодержавна, міжнародна;

5) ціль платежу: пов' язаний із підприємницькою діяльністю чи не пов' язаний із нею;

6) галузева приналежність основного зобов'язання: сфера цивільного чи публічного права (податкові розрахунки).

Отже, наведена класифікація є особливим методом, грамотне використання якого слугуватиме підвищенню ефективності правового регулювання, а правильне застосування сприятиме вдосконаленню нормативних актів i, урешті-решт, удосконаленню правового регулювання суспільних відносин.

Досліджувані відносини пропонуємо розглядати в різних аспектах: по-перше, соціальному; до-друге, матеріальному; по-третє, юридичному. Зокрема, розрахункові відносини за соціальним змістом є такими суспільними відносинами, які формуються внаслідок здійснення платежів із метою погашення грошового зобов'язання. Матеріальний зміст розрахункових відносин збігається з об'єктом розрахункових відносин, тобто є діями, спрямованими на погашення грошового зобов'язання [7, с. 110]. Сутність юридичного змісту розрахункових правовідносин виявляється в юридичних правах та обов' язках його суб'єктів.

Важливим є з'ясування правового регулювання кредитно-розрахункових відносин. У науковій літературі вчені розкривають сутність не тільки економічної та соціальної природи кредитно-розрахункових відносин, а й правової. Зокрема, Л. Г. Рябко вважає, що кредитно-розрахункові правовідносини - це врегульовані нормами права самостійного виду відносини, які виникають між учасниками майнового обороту з приводу надання грошових коштів і товарно-матеріальних цінностей на визначений термін або з відстрочкою платежу при перерозподілі мате- 
ріальних фондів на умовах терміновості, поворотності й платності у вигляді процентів за кредитом [8, с. 9]. Слушною є думка Г. І. Андрущенко, яка зазначає, що кредитно-розрахункові правовідносини мають зобов' язальний характер і побудовані з урахуванням довіри, часу, невизначеності, відстрочки, символічної платності, соціальної дієвості, що, у свою чергу, досягаються завдяки взаємній повазі, іміджу, честі та репутації суб'єктів кредитних правовідносин [9, с. 15].

Як бачимо, кредитно-розрахункові відносини як наукова категорія - поняття багатогранне, що потребує постійного дослідження (зокрема щодо розкриття цього поняття та проведення чіткого аналізу його сутності) і пошуку нових шляхів удосконалення.

Особливої уваги заслуговують кредитно-розрахункові відносини в країнах ЄС, оскільки в них ключові принципи та стандарти $є$ фундаментальною основою будівництва різноманітних інфраструктур фінансових ринків. Початком розробки та практичного впровадження таких стандартів і принципів вважається звіт, підготовлений групою експертів названого Комітету під керівництвом А. Ламфалуссі в 1990 р. (Lamfalussy report, Lamfalussy standards) [10]. У зв' язку з виявленням певних недоліків при застосуванні вказаних стандартів у 2001 р. були прийняті Ключові принципи для системно значущих платіжних систем [11]. У 2008 р. поєднання фінансово-економічної, політичної та банківської криз наклали свій відбиток на платіжні системи та розрахункові відносини у різних сферах і галузях. У результаті негативних наслідків країни СС створили новітню банківську систему, захищену від криз. Так у квітні 2012 р. Комітет представив оновлені Принципи для інфраструктур фінансового ринку [12].

Вважаємо за доцільне акцентувати увагу на Директиві 98/26/СС Свропейського Парламенту та Ради СС «Про незворотність розрахунків у платіжних системах та системах розрахунків по цінних паперах» (надалі - Директива), у якій наголошується, що «зменшення ризиків, пов' язаних з участю в системах розрахунків по цінних паперах, також має велике значення, зокрема в умовах, коли існує тісний зв' язок між такими системами та платіжно-розрахунковими системами» [13].

Слід зауважити, що в Комплексній програмі розвитку фінансового сектору України до 2020 р. [14] наголошується на необхідності імплементації в національне законодавство положень Директиви. Зокрема, пропонується здійснити такі перетворення:

1) створити рівні умови для конкуренції у фінансовому секторі;

2) запровадити спеціальні вимоги щодо капіталу, ліквідності та інших показників системно важливих банків та інших фінансових установ;

3) удосконалити системи регулювання та нагляду за фінансовим сектором;

4) забезпечити подальший розвиток безготівкового обігу та розвиток роздрібних безготівкових платежів із використанням електронних платіжних засобів.

Однак сьогодні в Україні окреслені перетворення не набули належного поширення, притаманного країнам СС. Тому дослідження економічного та правового аспектів кредитно-розрахункових відносин у контексті євроінтеграції $є$ одним із напрямів подальшого спостереження за предметом з метою наукового вивчення. 
Висновки. Здійснивши аналіз чинного законодавства України і загальний правовий аналіз досвіду країн СС, розглянувши зміст та сферу застосування розрахункових відносин, вважаємо за доцільне розширити поняття «розрахунки», адже його зміст не зводиться лише до банківських платежів, побудованих на засадах диспозитивності, а носить і публічні, фінансово-правові аспекти. Водночас варто наголосити на неоднозначності правової природи розрахунків та сфери їх застосування. Проводити однозначне відмежування розрахунків як економічного та правового явища не потрібно, оскільки в межах розрахункових відносин розрахунки мають економічне підгрунтя, та водночас здійснюється їх правове регулювання.

Вважаємо, що викладені теоретико-правові положення проведеного наукового дослідження сприятимуть поглибленню теорії розрахунків, розрахункових відносин та кредитно-розрахункових відносин зокрема, а пропозищії, надані під час наукового пошуку, сприятимуть вдосконаленню їх правового регулювання.

У подальшому з'ясування правової характеристики регулювання кредитнорозрахункових відносин крізь призму досвіду країн ЄС є перспективним напрямом наукових досліджень.

\section{Використані джерела:}

1. Подцерковный О. П. Организационно-правовые основы расчетных отношений в хозяйственном комплексе Украины: дис. ... канд. юрид. наук.: 12.00.04. Одесса, 1999. 191 с.

2. Хірс Я. О. Цивільно-правове регулювання розрахункових відносин за законодавством України: автореф. дис. ... канд. юрид. наук: 12.00.03. Київ, 2011. 18 с.

3. Теремецький В. І., Ігонін Р. В., Прийма С. В., Антонова О. Р. Фонд гарантування вкладів фізичних осіб як суб'єкт контролю за діяльністю банків в Україні. Збірник наукових праць «Фінансово-кредитна діяльність: проблеми теорї та практики». 2018. Вип. 4 (27). 2018. C. 79-87.

4. Ващенко Ю. В. Банківське право: навч. посібник. Київ : Центр навчальної літератури, 2006. 344 с.

5. Новоселова Л. А. Денежные расчеты в предпринимательской деятельности. Москва : ЮрИнфоР, 1996. 326 с.

6. Тимакова Т. Г. Финансово-правововое регулирование Центральным банком Российской Федерации внутригосударственных безналичных расчётов / под ред. проф. Н. И. Химичевой. Саратов : СГАП, 2005. 212 с.

7. Хірс Я. О. Теоретико-правові питання розрахунків. Юридичний вісник. Вип. 3 (28). 2013. C. 108-112.

8. Рябко Л. Г. Правове регулювання кредитно-розрахункових відносин по законодавству України: автореф. дис. ... канд. юрид. наук. Харків, 2008. 20 с.

9. Андрущенко Г. І. Кредитні відносини у структурі фонду життєвих засобів: соціологічний аспект: автореф. Дис. ... канд. соціол. наук. Київ, 2009. 23 с.

10. Review of the Lamfalussy process Strengthening supervisory convergence: Commu nication from the Commission. URL : https://ec.europa.eu/transparency/regdoc/?fuseac tion= list\&coteId=1\&year=2007\&number=727\&version=ALL\&language=en. (дата звернення: 10.10.2020).

11. General principles for international remittance services. Bank for International Settle ments, World Bank, 2007, January. 61 p. 
12. Principles for Financial Market Infrastructures. Bank for International Settlements and International Organization of Securities Commissions, 2012. URL : https://www.iosco.org/library/pubdocs/pdf/IOSCOPD396.pdf. (дата звернення: 10.10.2020).

13. Про незворотність розрахунків у платіжних системах та системах розрахунків по цінних паперах: Директива 98/26/ЄС Європейського Парламенту та Ради ЄС від 19.05. 1998. URL : https://zakon.rada.gov.ua/laws/show/994_455\#Text. (дата звернення: 10.10. 2020).

14. Комплексна програма розвитку фінансового сектору України до 2020 року: Постанова Правління Національного банку України від 18.06.2015 № 391. URL : https:/ / zakon. rada.gov.ua/laws/show/v0391500-15. (дата звернення: 10.10.2020).

\section{References:}

1. Podtserkovnyi, O. P. (1991) Orhanyzatsyonno-pravovye osnovy raschetnykh otnoshenyi v khoziaistvennom komplekse Ukrayny. Candidate's of thesis. Odessa. [in Russian].

2. Khirs, Ya. O. (2011) Tsyvilno-pravove rehuliuvannia rozrakhunkovykh vidnosyn za zakonodavstvom Ukrainy. Extended abstract of candidate's thesis. Kuiv. [in Ukrainian].

3. Teremetskyi, V. I., Ihonin, R. V., Pryima, S. V., Antonova, O. R. (2018) Fond harantuvannia vkladiv fizychnykh osib yak sub'iekt kontroliu za diialnistiu bankiv v Ukraini. "Zbirnyk naukooykh prats «Finansovo-kredytna diialnist: problemy teorii ta praktyky"- Collection of scientific works "Financial and credit activity: problems of theory and practice", issue 4 (27), 79-87. [in Ukrainian].

4. Vashchenko, Yu. V. (2006) Bankivske pravo: navch. posibnyk. Kyiv : Tsentr navchalnoi literatury. [in Ukrainian].

5. Novoselova, L. A. (1996) Denezhnye raschety v predprinimatelskoj deyatelnosti. Moskva :YurInfoR. [in Russian].

6. Timakova, T. G. (2005) Finansovo-pravovovoe regulirovanie Centralnym bankom Rossijskoj Federacii vnutrigosudarstvennyh beznalichnyh raschyotov. N. I. Himicheva (Ed.). Saratov : SGAP. [in Russian].

7. Khirs, Ya. O. (2013) Teoretyko-pravovi pytannia rozrakhunkiv. Yurydychnyi visnyk- Legal Bulletin, vol. 3 (28), 108-112. [in Ukrainian].

8. Riabko, L. H. (2008) Pravove rehuliuvannia kredytno-rozrakhunkovykh vidnosyn po zakonodavstvu Ukrainy. Extended abstract of candidate's thesis. Kharkiv. [in Ukrainian].

9. Andrushchenko, H. I. (2009) Kredytni vidnosyny u strukturi fondu zhyttievykh zasobiv: sotsiolohichnyi aspekt. Extended abstract of candidate's thesis. Kyiv. [in Ukrainian].

10. Review of the Lamfalussy process Strengthening supervisory convergence: Commu nication from the Commission. N. d. N. p. URL : https://ec.europa.eu/transparency/regdoc/ ?fuseaction=list\&coteId=1\&year=2007\&number=727\&version=ALL\&language=en. [in English].

11. General principles for international remittance services. (2007) Bank for International Settlements, World Bank, 2007, January. 61 p. [in English].

12. Principles for Financial Market Infrastructures. (2012) N. p. Bank for International Settlements and International Organization of Securities Commissions, 2012. URL : https:// www.iosco.org/library/pubdocs/pdf/IOSCOPD396.pdf. [in English].

13. Pro nezvorotnist rozrakhunkiv u platizhnykh systemakh ta systemakh rozrakhunkiv po tsinnykh paperakh: Dyrektyva 98/26/IeS Yevropeiskoho Parlamentu ta Rady YeS vid 19.05.1998. (1998) N. p. URL:https:/ /zakon. rada.gov.ua/laws/show/994_455\#Text. [in Ukrainian].

14. Kompleksna prohrama rozvytku finansovoho sektoru Ukrainy do 2020 roku: Postanova Pravlinnia Natsionalnoho banku Ukrainy vid 18.06.2015 № 391. (2015) N. p. URL : https:// zakon.rada.gov.ua/laws/show/v0391500-15. [in Ukrainian]. 
Бугайчук В. С., аспирант кафедры конституционного, административного и финансового права

Академии труда, социальных отношений и туризма (г. Киев, Украина)

\section{ПРАВОВАЯ ХАРАКТЕРИСТИКА РЕГУЛИРОВАНИЯ КРЕДИТНО-РАСЧЕТНЫХ ОТНОШЕНИЙ СКВОЗЬ ПРИЗМУ ОПЫТА СТРАН ЕВРОПЕЙСКОГО СОЮЗА}

В статье исследована сущность понятия кредитно-расчетных отношений, охарактеризованы различные подходы и классификационные особенности их правового регулирования с учетом опыта стран Европейского Союза. Установлено, что причиной возникновения расчетных отношений является явление правовой действительности. Проведено разграничение понятий «расчеты», «расчетные правоотношения» и «кредитно-расчетные отношения». Осуществлена классификация расчетных отношений. Проанализированы кредитно-расчетные отношения в странах Европейского Союза; предложено осуществить преобразования, способствующие совершенствованию правового регулирования исследуемых отношений.

Ключевые слова: расчет, платеж, правоотношения, кредитно-расчетные отношения, юридическое содержание расчетных отношений, ЕС.

\section{Bugaychuk V., \\ Graduate Student of the Department of Constitutional, Administrative and Financial Law Academy of Labor, Social Relations and Tourism}

(Kyiv, Ukraine)

\section{LEGAL CHARACTERISTICS OF REGULATING CREDIT AND BILLABLE RELATIONS THROUGH THE PRISM OF THE EXPERIENCE OF THE EUROPEAN UNION COUNTRIES}

The author of the article has researched the essence of the concept of "credit and billable relations", which scholars consider both in broad and narrow senses. Different approaches and classification features of legal regulation of such relations have been characterized taking into account the experience of the European Union countries. Differentiation between the concepts of "settlement accounts", "settlement legal relations" and "credit and billable relations" has been carried out. It has been established that the prerequisite for the emergence of settlement relations is the phenomenon of legal reality. It has been determined that the settlement relations by their legal nature are diverse and complex at the same time. In order to effectively regulate the procedure of realizing settlement accounts, it is necessary to clearly understand the essence of such relations, their content and features. The essence of settlement relations has been clarified through the implementation of one of the most common methods of legal technique used by legal scholars to establish the truth while studying legal phenomena, decisions, some scientific problems - classification, which comprehensively revealed the idea about the types of settlement accounts. It has been found out that the category of credit and billable relations was 
not properly addressed in rule-making and law-enforcement practice. The author has analyzed credit and billable relations in the countries of the European Union and has offered to carry out transformations, which can promote the improvement of legal regulation of the researched relations, in particular to create equal conditions for competition in the financial sector; to introduce special requirements in regard to capital, liquidity and other indicators of systemically important banks and other financial institutions; to improve the systems of regulation and supervision over the financial sector; to ensure further development of non-cash circulation and development of retail non-cash payments using electronic means of payment.

Keywords: settlement of accounts, payment transaction, legal relations, credit and billable relations, legal content of settlement relations, European Union.

DOI: 10.33766/2524-0323.92.93-104

УДК 343.352

В. О. Веретянніков, начальник навчально-методичного відділу, здобувач Луганського державного університету внутрішніх справ імені Е. О. Дідоренка (м. Сєвєродонецьк, Україна) e-mail: vladimirveretyannikov@gmail.com iDhttps:/ / orcid.org/ 0000-0001-7513-2292

\section{ПРАВОЗАСТОСОВНЕ ТЛУМАЧЕННЯ ПРОВОКАЦІЇ КРИМІНАЛЬНОГО ПРАВОПОРУШЕННЯ В ПРАКТИЦІ ЄВРОПЕЙСЬКОГО СУДУ 3 ПРАВ ЛЮДИНИ}

У статті проаналізовані вироблені практикою Європейського суду з прав людини основні підходи до визначення юридичного змісту та меж провокації кримінального правопорушення як неприпустимої поведінки з боку представників правоохоронних органів або інших осіб, яких правоохоронщі спонукають на провокаційну поведінку. Установлено, що така поведінка утворює порушення права особи на справедливий суд у контексті ч.1 ст. 6 Конвенщії про захист прав людини й основоположних свобод.

Також запропоновано авторське узагальнення критеріїв та ознак провокації кримінального правопорушення, які повинні враховуватися вітчизняними правоохоронними органами і судами в процесі як реалізації, так і юридичної оцінки різних форм контролю за вчиненням протиправного діяння.

Ключові слова: провокація, право на справедливий суд, співучасть у злочині, негласні слідчі (розшукові) дії, контроль за вчиненням злочину.

Постановка проблеми. «Давно сформованою позищією Свропейського Суду $\epsilon$ те, що суспільні інтереси не можуть обгрунтовувати використання доказів, отриманих у результаті поліцейської провокації, оскільки застосування таких доказів 3 самого початку піддасть обвинуваченого ризику позбутися справедливого судового розгляду» [1]. Ця позищія Свропейського суду з прав людини (далі - ССПЛабо Європейський Суд), висловлена 2016 року в справі «Баннікова проти Росіі» (п.34) певним чином орієнтує і чинну практику цього Суду, і національні суди державучасниць Конвенщії про захист прав людини й основоположних свобод 1950 р. (далі 